\title{
Determination of some Quality Characteristics in Chickpea (Cicer arietinum L.) Genotypes and Relationships between Characteristics
}

\author{
Sinem Tuğçe Cin ${ }^{1, a}$, Nurdoğan Topal ${ }^{1, b, *}$ \\ ${ }^{I}$ Department of Field Crops, Faculty of Agriculture, Uşak University, 64000 Uşak, Turkey \\ *Corresponding author \\ A R T I C L E I N F O A B S T R A C T \\ Research Article \\ Chickpea (Cicer arietinum L.) is one of the important plants in terms of nutrition. The yield and \\ quality studies on chickpea, which has the highest production value among edible grain legumes, \\ continue at full stem in our country. When it comes to quality, certain consumer expectations such \\ as protein content, cooking time and seed coat ratio dominate the quality improvement. This study \\ was conducted according to the experimental designs of randomized blocks under the Faculty of \\ Agriculture and Natural Sciences, Uşak University and the laboratory conditions of Faculty of \\ Agriculture, Ondokuz Mayıs University. In this study, a total of 30 chickpea genotypes were used, \\ 13 of them have different varieties. Cooking Time (min), Water Absorption Index (\%), Seed Coat \\ Rate $(\%)$, Protein Rate $(\%)$ and Amylose Rate $(\%)$ values of the genotypes have been obtained. The \\ statistically significant differences have been detected between the genotypes in terms of all \\ parameters examined in the variance analysis conducted as a result of this study. Similarly, the \\ result of this study has revealed the correlation between the properties. This study was obtained \\ Keywords: \\ Water Absorption Index \\ Protein Ratio \\ from a part of the master's thesis.
}

Amylose Ratio

Cooking Time Introduction

\section{Introduction}

Chickpea (Cicer arietinum L.), which is a genus Cicer in the Papilionoideae subfamily of Leguminosae (legumes) family, is one of the old-world plants grown in Central and South Asia, South Europe, Ethiopia and North Africa. The Cicer genus contains 44 species, 35 of which are perennials, 8 of them are annuals and one of them is $\mathrm{C}$. arietinum L. that is currently in use. C. Arietinum contains two species, namely the small-seeded Desi and largeseeded Kabuli. Desi groups are mostly grown in Africa and India while Kabuli-type chickpeas are generally grown in Eastern Asia, Northern Africa, South America and Europe (Jukanti et all., 2012). In our country, Kabuli-type chickpeas are widely grown. Kabuli-type chickpeas have large seeds and carbohydrate and protein ratios are high (El-Adawy, 2002). Chickpea, the most widely preferred species after soybean, is highly important due to its capacity of symbiotic nitrogen fixation and the nutrients it contains (Varshney et al., 2013). As it needs a crop rotation, the use of nitrogenous commercial fertilizer/manure is decreasing. Thus, both input cost is reduced and the pollution of soil, groundwater and air is prevented (Aydoğan, 2012). The rich protein content, calcium and cellulose content in seed coat, and the rich carbohydrates, vitamin and mineral content prove the importance of chickpea for human nutrition (Ercan et al., 2005: Erbaş Köse and Mut, 2019).

Chickpea is grown in an area of approximately 17 million ha worldwide (FAO, 2020). India is the country having the most cultivation area in the world with approximately 11 million ha land; which is followed by Australia with 1 million ha and Pakistan with 976 thousand ha land, respectively. Turkey is the fifth country with 514 thousand ha cultivation land (FAO, 2020). 2018 data reveals that Turkey has 514 thousand ha land for chickpea cultivation and the annual production is 630 thousand tons in Turkey (TUIK, 2020).

Erbas Köse and Mut (2020) reported among the edible legumes, chickpea has quite high nutritional values and mineral matter content, thus commonly grown and consumed worldwide. The primary quality criteria in 
chickpea are seed size, seed shape and color, yet its protein content, digestibility rate, seed coat rate, amylose rate and cook time rate are also important. Singh et al. (1986) have reported that cook time is an important criterion in determining heredity level and soaking the seeds one night before cooking shortens the cooking time. They also have reported that different soaking times and regional characteristics where chickpea was grown affects the cooking time, and protein ratio also changes depending on the location where the plant was grown.

Kaya et al. have compared the local genotypes with the quality criteria and agricultural characteristics of the patented chickpea varieties. The results have revealed that average raw protein rate is $18.24-27.57 \%$, seed coat rate is $0.66-3.07 \%$ and the cooking time is approximately $30-90$ minutes (Kaya et al., 2016). This study was conducted to compare some patented chickpea varieties with the quality characteristics of chickpea genotypes obtained from difference provinces of Turkey, and to determine certain quality characteristics of local chickpea genotypes.

\section{Material and Method}

This study was conducted in the laboratories of Faculty of Agriculture and Natural Sciences, Usak University in 2019. The experimental design of randomized plots was used. The local seed materials used in the study were obtained from farmers producing chickpeas in Uşak, Afyon, Kütahya, Manisa, Denizli, Mersin, Aydın and Konya provinces. In this study, a total of 30 chickpea samples were used and 17 of them are local and 13 of them are patented (Table 1). This study has examined protein rate $(\%)$, amylose rate $(\%)$, chickpea seed coat rate $(\%)$, seed water absorption rate (\%), and cooking time (min). SPSS 23 Package Program was used for the variance analysis of the data.

Cooking time (Minute): In order to determine the cooking time, the hotplate was set 200 degrees and the samples were placed in $150 \mathrm{ml}$ boiling pure water, and it was recorded as the cooking time once the cotyledons of chickpeas disappeared (Anonymous, 2001).

Water absorption index (\%): The dry weights of the samples were weighted for this purpose and placed in 250 $\mathrm{ml}$ Erlenmeyer flask and $50 \mathrm{ml}$ distilled water was added. After keeping the seeds at 20 degrees for 24 hours, the wet weight was recorded and its water absorption index was calculated according to the formula (Gülümser at al., 2008).

Seed Coat Rate (\%): In order to determine the seed coat rate, the seeds which were used to determine the water absorption rate were peeled off and wet weight of the coats were recorded. The wet-weighted coats were dried at 80 degrees for 24 hours. Coat rate was calculated according to the formula (Gülümser at al., 2008).

Protein Rate (\%): It was calculated according to Kjeldahl method. All trials in this research were based on 3 repetitions. The data obtained were concluded according to the DUNCAN test. Genotype coding and definitions are presented in Table 1 below (Bayrak, 2010).

Amylose Rate (\%): The method of Karayel (2012) was used in determining the amylose rate of chickpea genotypes.
Table 1. Information on Genotypes Used in the Trial

\begin{tabular}{|c|c|c|c|c|}
\hline $\mathrm{G}$ & $\mathrm{V} / \mathrm{P}$ & G. Name & Seed Type & Seed Shape \\
\hline 1 & $\mathrm{~V}$ & Ihvd.17.114 & Kabuli & ssp.arieticeps \\
\hline 2 & V & Ihvd.17.125 & Kabuli & ssp.pisiforme \\
\hline 3 & V & Çağatay & Kabuli & ssp.arieticeps \\
\hline 4 & V & Gülümser & Kabuli & ssp.pisiforme \\
\hline 5 & V & Zuhal & Kabuli & ssp.arieticeps \\
\hline 6 & V & Sezenbey & Kabuli & ssp.pisiforme \\
\hline 7 & V & Akça & Kabuli & ssp.arieticeps \\
\hline 8 & V & Çakır & Kabuli & ssp.pisiforme \\
\hline 9 & V & Iş1k-05 & Kabuli & ssp.arieticeps \\
\hline 10 & V & Yaşa-05 & Kabuli & ssp.arieticeps \\
\hline 11 & V & Hisar & Kabuli & ssp.pisiforme \\
\hline 12 & V & Azkan & Kabuli & ssp.pisiforme \\
\hline 13 & V & Sar1-98 & Kabuli & ssp.pisiforme \\
\hline 14 & $\mathrm{P}$ & Bozkurt Çambaşı & Desi & ssp.intermedium \\
\hline 15 & $\mathrm{P}$ & Bozkurt Tutluca & Kabuli & ssp.pisiforme \\
\hline 16 & $\mathrm{P}$ & Baklan & Kabuli & ssp.intermedium \\
\hline 17 & $\mathrm{P}$ & Argun & Kabuli & ssp.arieticeps \\
\hline 18 & $\mathrm{P}$ & Baltalı & Kabuli & ssp.pisiforme \\
\hline 19 & $\mathrm{P}$ & Dinar & Kabuli & ssp.arieticeps \\
\hline 20 & $\mathrm{P}$ & İspanyol & Kabuli & ssp.arieticeps \\
\hline 21 & $\mathrm{P}$ & Örenpınar & Kabuli & ssp.arieticeps \\
\hline 22 & $\mathrm{P}$ & Meksika & Kabuli & ssp.arieticeps \\
\hline 23 & $\mathrm{P}$ & Mikser & Kabuli & ssp.arieticeps \\
\hline 24 & $\mathrm{P}$ & Çumra & Kabuli & ssp.arieticeps \\
\hline 25 & $\mathrm{P}$ & Gediz & Desi & ssp.intermedium \\
\hline 26 & $\mathrm{P}$ & Seydiler & Kabuli & ssp.arieticeps \\
\hline 27 & $\mathrm{P}$ & Haskan & Kabuli & ssp.intermedium \\
\hline 28 & $\mathrm{P}$ & Çandır & Kabuli & ssp.intermedium \\
\hline 29 & $\mathrm{P}$ & Ethem & Kabuli & ssp.intermedium \\
\hline 30 & $\mathrm{P}$ & Selim & Kabuli & ssp.pisiforme \\
\hline
\end{tabular}

G: Genotype Number, V/P: Variety/Population

\section{Results and Discussion}

The results of variance analysis regarding seed coat rate $(\%)$, cooking time (min.), amylose rate $(\%)$, protein rate $(\%)$ and water absorption index (\%) are presented in Table 2.

Table 2 reveals that statistically significant differences $(\mathrm{P}<0.01)$ have been determined in all parameters examined among the genotypes. It is assumed that these differences have resulted from genotypic differences.

Seed Coat Rate (\%): Coat rate in legumes is an important criterion as it is a primary element for quality criteria and it also shapes the consumers' preferences. A study examining the correlation between the heredity of seed coat thickness, flower color and seed size reported that the thickness of seed coat shows a monogenic inheritance and the characteristics of thin coat has a recessive form (Gil et al., 1996). The results of the variance analysis show that there are statistically significant differences between the genotypes (Table 2). Following the Duncan multiple comparisons regarding the coat rate with a genotype average of $4.3 \%$, it has seen that the genotypes having the highest value in terms of coat rate are the local genotypes of Örenpınar ${ }^{\mathrm{a}}$, Argun $^{\mathrm{ab}}$ and Mikser ${ }^{\mathrm{ab}}$ while the genotypes having the lowest value are Yaşa- $05^{\mathrm{m}}$, Hisar ${ }^{\mathrm{lm}}$ and

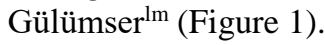

Yalcin et al. (2018) have determined the seed coat rates (\%) of genotypes as 5.21-6.0 in their study which was conducted in eight chickpea genotypes under the conditions of Afyonkarahisar and Yozgat provinces. 
Table 2. Variance Analysis Results for Examined Properties

\begin{tabular}{|c|c|c|c|c|c|c|}
\hline Source & Dependent Variable & Type III Sum of Squares & $\mathrm{df}$ & Mean Square & $\mathrm{F}$ & Sig. \\
\hline \multirow{5}{*}{ Genotypes } & Seed Coat Rate $(\%)$ & 41.137 & 29 & 1.419 & 9.882 & 0.000 \\
\hline & Water Absorption Index (\%) & 0.329 & 29 & 0.011 & 15.873 & 0.000 \\
\hline & Protein Rate $(\%)$ & 183.598 & 29 & 6.331 & 7.112 & 0.000 \\
\hline & Cooking Time (Minute) & 8489.225 & 29 & 292.732 & 31.280 & 0.000 \\
\hline & Amylose Rate (\%) & 467.409 & 29 & 16.118 & 93.954 & 0.000 \\
\hline \multirow{5}{*}{ Error } & Seed Coat Rate $(\%)$ & 8.613 & 60 & 0.144 & & \\
\hline & Water Absorption Index $(\%)$ & 0.043 & 60 & 0.001 & & \\
\hline & Protein Rate $(\%)$ & 53.408 & 60 & 0.890 & & \\
\hline & Cooking Time (Minute) & 561.500 & 60 & 9.358 & & \\
\hline & Amylose Rate (\%) & 10.293 & 60 & 0.172 & & \\
\hline
\end{tabular}

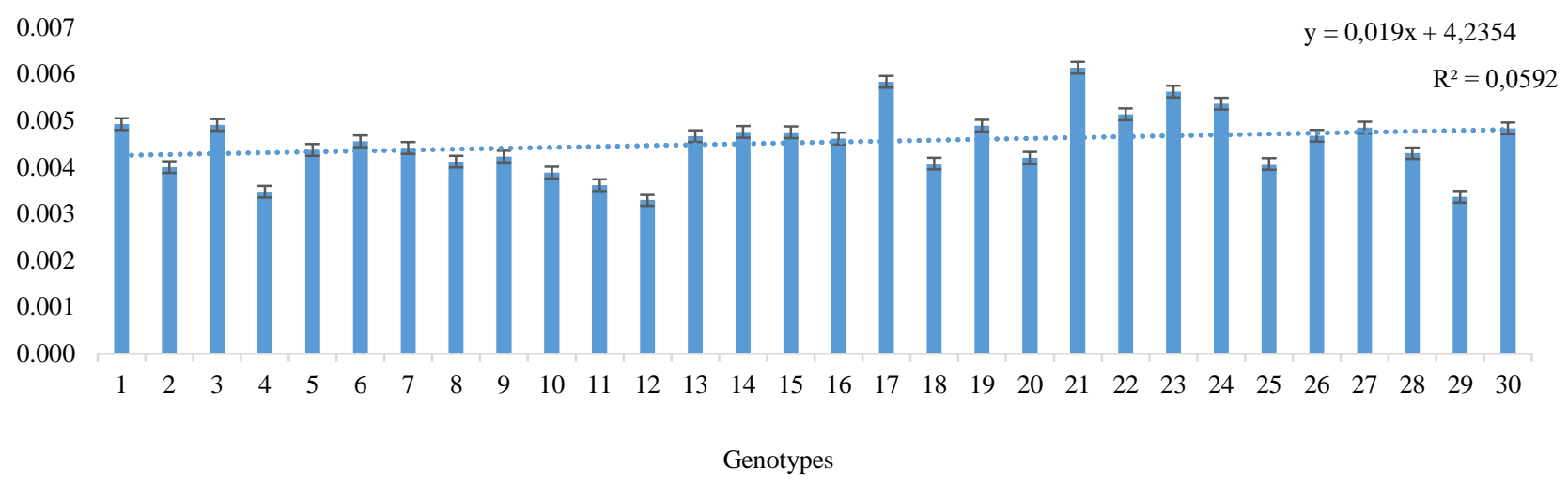

Figure 1. Seed Coat Rate of the Genotypes (\%)

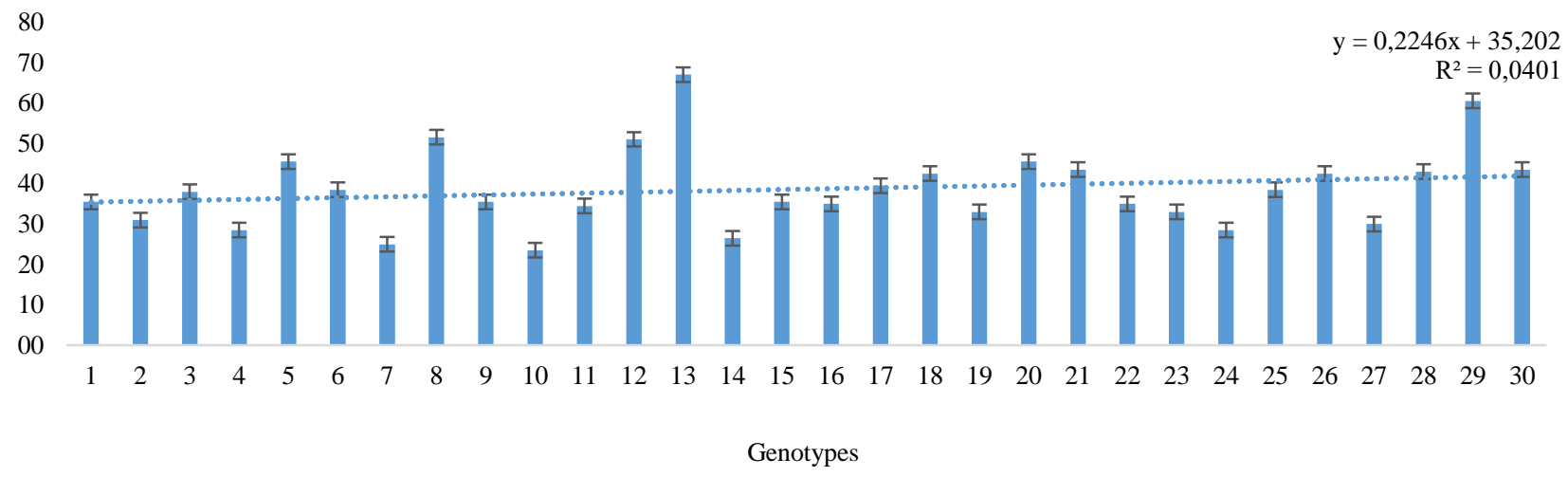

Figure 2. Cooking Times of the Genotypes (Minute)

Another study, which was conducted by Kaya et al. (2016), and titled "Evaluation of Chickpea Genotypes Grown in the provinces of Lakes Region in terms of Certain Quality and Technological Properties", has revealed that seed coat rate is $0.66-3.07 \%$. In another study conducted for 2 years, Damla-89 type of chickpea was used and seed coat rate has been determined as $5.46 \%$ (Mut and Gülümser, 2005). Out study has determined that seed coat rates of the genotypes are between $3.7-6.1 \%$. It is seen that our values are similar when compared to the literature.

Cooking Time (Minute): As in all legumes family; protein content, nutritiousness, amino acid composition, the amount of vitamins and minerals are important quality parameters as well as coat rate and water absorption rate, especially the structure, appearance and aroma of the cooked seed and its cooking time. In addition to the aforementioned quality criteria, cooking time has an impact on the selection in breeding works, and consumers demand a thin coat structure and short cooking time that gives a good appearance, taste and flavor. The long cooking time decreases nutrition value and its acceptability and results in high energy loss (Karaduman et al., 2017). Cooking times means of genotypes are given in Figure 2.

The results of the variance analysis show that there are statistically significant differences detected between the genotypes as in seed coat rate $(\mathrm{P}<0.01)$. Following the Duncan multiple comparison regarding the average cooking time of 38,7 minutes for the genotypes, it is seen that the genotype no. $13^{\mathrm{a}}$ (Sar1 98) has the longest cooking time while the genotype no. $10^{\mathrm{k}}$ (Yaşa-05) has the shortest cooking time. Local populations used in the trial has a cooking time below the average cooking time. Akıncı et al. (2017) used 18 genotypes in their study "Determination of the Resistance of Winter Chickpea Genotypes to Cold and Anthracnose as well as the Cooking Properties of the Seed", and they have reported that the cooking time for the genotypes varies between 43-59 minutes and the highest cooking time is recorded in local chickpeas. In their study 
"Evaluation of Chickpea Genotypes Grown in the Provinces of Lakes Region in terms of Certain Quality and Technological Properties", Kaya et al. (2016) have stated that the cooking time interval of the genotypes is 55-200 minutes (Williams et al., 1983). Another study conducted on the chickpea genotypes of five desi and five kabuli has revealed that kabuli-type chickpeas has a 72-96 minutes of cooking time while the cooking time of desi-type chickpeas varies between 72-76 minutes (Singh et al., 1991). In a study conducted by Tripathi et al. (2012) with 44 kabuli and 42 desi-type chickpeas, it has shown that the cooking times vary 38-125 minutes between genotypes. In another study, 91 local chickpea lines and 2 control types were used and the cooking time has been reported as 33-72 minutes (Özer et al., 2010). Our study shows similar results when it is compared with the literature.

Water Absorption Index (\%): Water absorption rate of seeds in the chickpea genotypes vary depending on the unique seed characteristics of the genotype (Mut and Gülümser, 2005). The average water absorption index of the genotypes obtained from the study is presented in Figure 3.

The result of the variance analysis showed that there are statistically significant differences $(\mathrm{P}<0.01)$ between the genotypes in terms of water absorption index. The local genotype of Bozkurt Çambaşı $\left(1.20^{\mathrm{a}}\right)$ and the variety of Sezenbey $\left(1.23^{\mathrm{a}}\right)$ provided the best average in terms of water absorption index (\%) while the varieties of Hisar $\left(0.95^{\mathrm{i}}\right)$ and Azkan $\left(0.98^{\mathrm{i}}\right)$ gave the lowest average. Kaya et al. (2016) have stated in their study that the water absorption interval of the genotypes is $0.47-3.46 \%$. Uzun et al. (2012) have stated in their study "Evaluation of
Certain Selected Chickpea (Cicer arietinum L.) Lines in terms of Agronomic and Quality Characteristics" that there are significant differences $(\mathrm{P}<0.05)$ between the water absorption index $(\%)$ of the genotypes. They have reported that water absorption index (\%) of the genotypes varies between 1,008 to 1,112 . In another study conducted on TAEK Sağel mutant Chickpea genotype, Sağel et al. (2008) have stated that the water absorption index (\%) of the genotype is 1.15 . In our study, the average of the genotypes was found to be 1.094. Our results are similar to the literature.

Protein Rate (\%): Protein is essential for human growth and essential amino acids can only be obtained from food we eat (Grigg, 1995). One of the main nutritional sources is plants. Edible grain legumes are cheap and high-quality vegetable protein sources. The protein content of seeds is approximately $20-25 \%$, which is almost two times more than legume kernels (Pekşen and Artık, 2005). Chickpea is a legume plant that contains $21.0-23.9 \%$ protein in its dry grain and is superior to other legumes in terms of protein (Bayrak et al., 2005). The protein rates of the genotypes detected in our study is presented in Figure 4.

Our study shows that the average of genotypes in terms of protein ratio (\%) is 23,414 . The results of variance analysis between the genotypes have revealed that there are significant differences $(\mathrm{P}<0.01)$ in terms of protein rate (\%). The comparison of the genotypes indicates that Haskan local genotype has the highest protein rate with a value of $27.26^{\mathrm{a}} \%$ while the lowest rates are again obtained from the local genotypes of Baltalı $\left(\% 20.20^{\mathrm{g}}\right)$ and Çumra $\left(\% 20.40^{\mathrm{g}}\right)$.

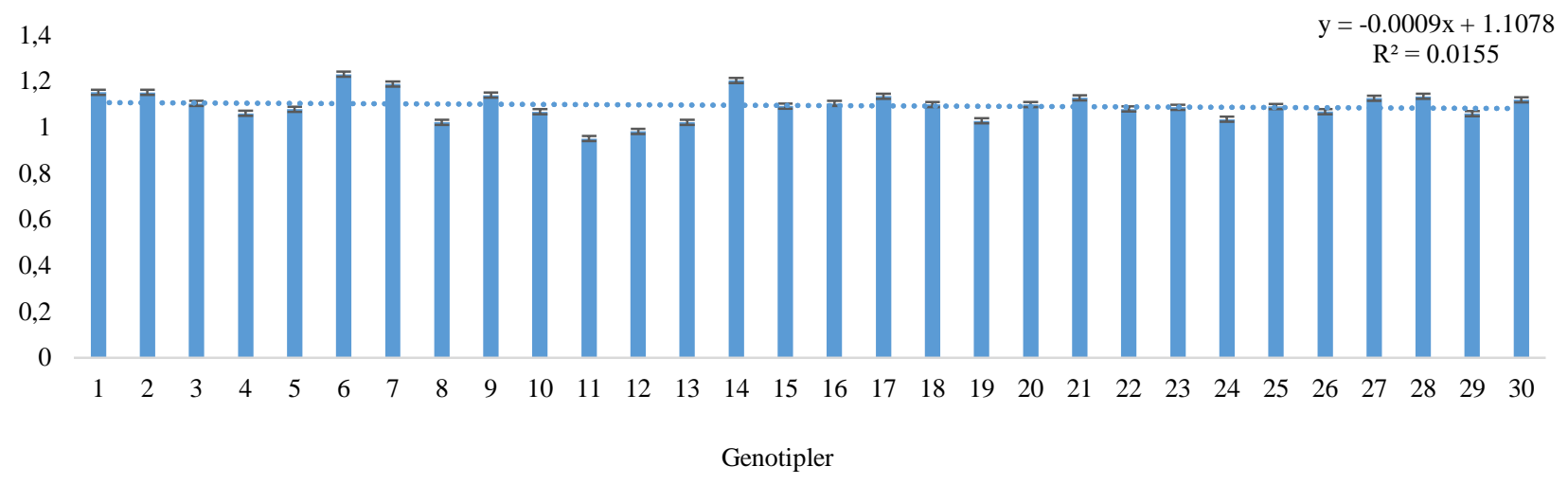

Figure 3. Water Absorption Index of the Genotypes (\%)

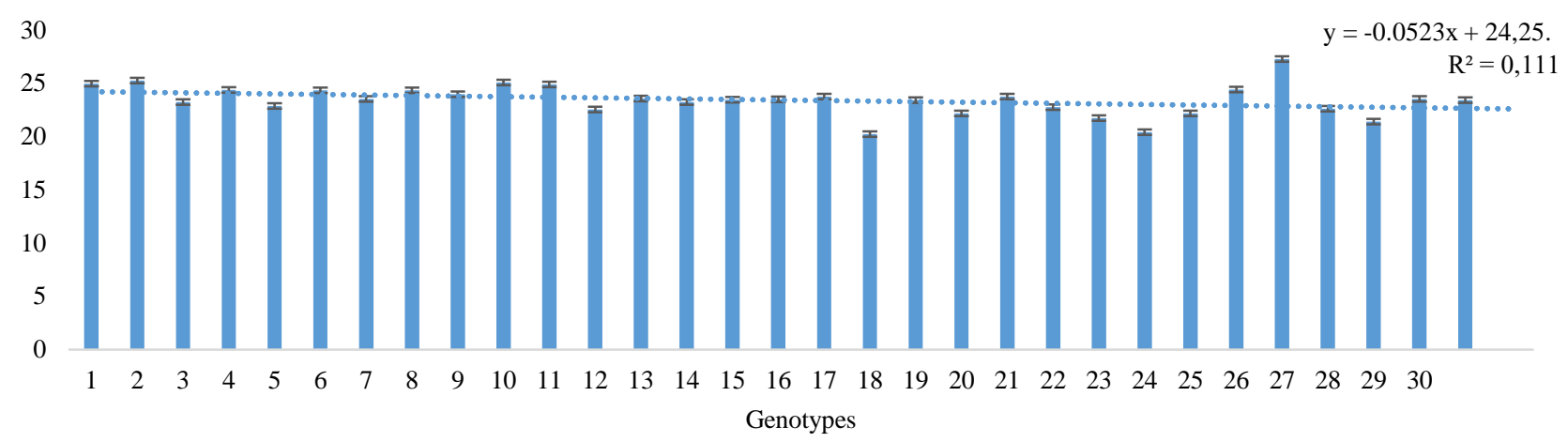

Figure 4. Protein Rates of the Genotypes (\%) 


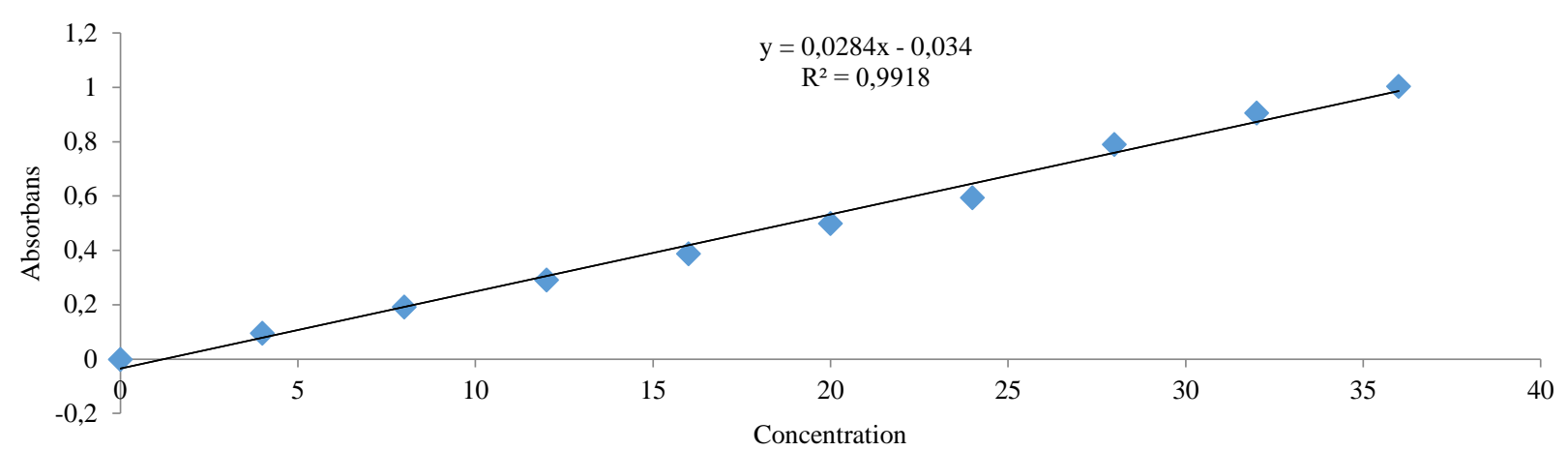

Figure 5. Amylose Calibration Curve

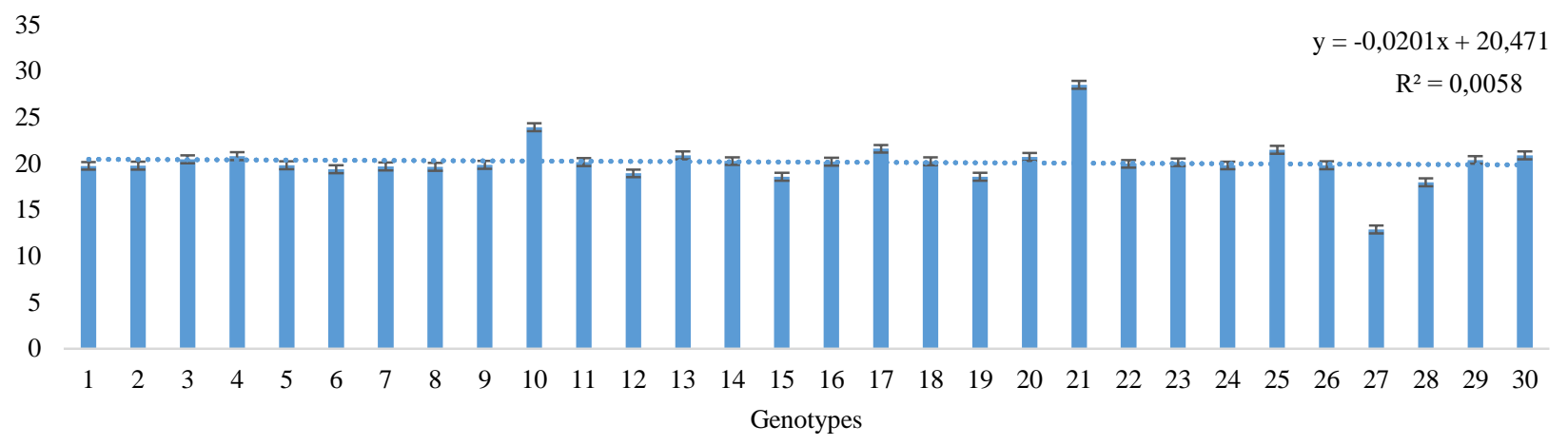

Figure 6. Amylose Ratios of Genotypes (\%)

Tayyar et al. (2008) conducted a study to examine the impacts of summer and winter time plantation for fourteen chickpea varieties and this study found that protein rates of chickpea genotypes are $19.6-21.1 \%$ in winter plantation and $22.2-24.6 \%$ in summer plantation. Another study showed that the protein rates of 10 different chickpea genotypes grown under different nutrition and drought conditions vary between 19.71-19.80\% (Kahraman et al., 2014). Khattak et al. (2006) specified protein rates as $18.08-19.02 \%$ in their studies conducted to determine the quality and morphological properties in kabuli-type chickpea genotypes. In a study titled "Impact of Stable Manure Dust on the Yield and Quality of Chickpea (Cicer arietinum L.), it has been determined that the rate of raw protein in grain varies between $18.90-21.56 \%$ (Karayel ve ark., 2020). Yalçin et al. (2018) reported that the protein rates of 8 different chickpea cultivars grown under different location vary between 19.96 to $24.05 \%$. Compared with previous studies, protein rates are found to be relatively higher in our study. We believe that this situation is resulted from genetic differences. The fact that local genotypes are promising in terms of protein rates increases their potential of being a breeding material.

Amylose Rate (\%): Legume seeds, also known as "both the meat and bread of the poor" among the public, has high carbohydrate rate $(15-65 \%)$ as well as high protein rate (Çulha and Bozoğlu, 2017). Carbohydrates are largely stored as starch in legumes (Pekşen and Artık, 2005). Seed starch consists largely (98-99\%) of amylose and amylopectin. Amylose content and long amylopectin chains prolong retrogradation (reduced starch solubility) and thus reduce glucose released in the blood. Besides, beneficial probiotics take effect for colonic microflora and consequently trigger a lower glycemic index (Tayade et al., 2019). Amylose Calibration Curve and Amylose Rates of the Genotypes are presented in Figure 5 and 6.

The results of statistical analysis have revealed highly significant differences $(\mathrm{P}<0.01)$ between the Genotypes and the genotype average in terms of amylose rate $(\%)$ has been found to be $20.160 \%$. Örenpinar genotype $\left(28.502^{\mathrm{a}}\right)$ and Yaşa-05 $\left(23.907^{\mathrm{b}}(\%)\right.$ variety have the highest amylose rate among the genotypes while Haskan local genotype has the lowest value of $12.868^{\mathrm{k}}$. The study conducted by Singh et al. (2004) on six commercial chickpea varieties showed that the amylose rates of the chickpeas have varied between 28.6-34.3\%. A study conducted to determine the starch properties of desi and kabuli-type chickpeas planted in China showed that the amylose rate varies between 29.93$31.80 \%$ in kabuli-type chickpeas while it varies between 31.11-35.24\% in desi-type chickpeas (Miao et al., 2009). In another study comparing the starch properties of cowpea, chickpea and green pea, it was found that cowpea amylose rate is $25.8 \%$, chickpea amylose rate is $27.2 \%$ and green pea amylose rate is $31,2 \%$ (Huang et al., 12007). Yañez-Farias et al. (1997) determined the amylose rate of bean as $52,4 \%$ and the amylose rate of chickpea as $46.5 \%$ in their study "Partial Starch Characterization and Isolation of Bean and Chickpea". Kaur and Singh (2006) determined the amylose rate as $28.6-34.3 \%$ in another study conducted on desi and kabuli-type chickpeas. It is thought that the differences in the amylose rates of the genotypes determined in our study result from genetic structure.

Relations Between the Characteristics (Correlation): Correlation data for the relations between the characteristics is presented in Table 3 . 
Table 3. Correlation data for the relations between the characteristics

\begin{tabular}{|c|c|c|c|c|c|}
\hline Characteristics & S.C.R & W.A.I & P.R & C.T & A. R \\
\hline S.C.R & 1 & & & & \\
\hline W.A.I & $0.367^{* *}$ & 1 & & & \\
\hline P.R & 0.001 & 0.098 & 1 & & \\
\hline C.T & $-0.222^{*}$ & $-0.305^{* *}$ & $-0.203^{*}$ & 1 & \\
\hline A. $\mathrm{R}$ & $0.211^{*}$ & 0.010 & $-0.196^{*}$ & 0.118 & 1 \\
\hline
\end{tabular}

Time (Minute), A. R: Amylose Rate (\%)

A study analyzing the quality characteristics of some dry bean varieties has determined that there is positive and insignificant correlation between Protein rate (\%), Cooking Time (min) and Water Absorption Index (\%); and there is significant and positive correlation of $1 \%$ between Cooking Time (min) and Water Absorption Index (\%) (Cengiz, 2007). In another study analyzing the correlation between quality and yield in chickpea, it has been demonstrated that there is a phenotypically negative and insignificant correlation between Protein rate $(\%)$ and carbohydrate rate (Ali et al., 2011). Correlation table (Figure 9) shows that there is a positive and significant relation between coat rate $(\%)$ and water absorption index $(\%)$ and amylose rate $(\%)$ while there is a negative and significant relation with cooking time (min). Water absorption index (\%) has negative and significant relation with cooking time $(\mathrm{min})$ while no significant relation is found between protein rate $(\%)$ and amylose rate.

This study, which was conducted on certain varieties (13) and local populations (17), has determined statistically highly significant differences $(\mathrm{P}<0.01)$ between the genotypes in terms of the examined parameters of quality criteria. Among the parameters examined, Örenpınar local population is the genotype with the highest coat rate while Gülümser chickpea variety has the lowest value. Cooking time ( $\mathrm{min}$ ) is one of the leading quality elements in terms of consumers and the variety of Yaşa-05 gave the best value with 23.5 minutes among the parameters analyzed and another variety called Akça took the second place with 25 minutes. Bozkurt Çambaşı genotype, which is one of the local populations, ranked third with 26.5 minutes. Cooking time in local populations was below the genotype average (Figure 4). For water absorption index (\%), Bozkurt Çambaşı (1.20) local genotype and Sezen Bey (1.23) variety gave the highest rate while Hisar (0.95) and Azkan (0.98) were placed at the end. The comparison of the genotypes in terms of protein rate $(\%)$ which is another quality factor has showed that Haskan genotype has the highest protein rate with $27.26 \mathrm{a} \%$ while the local genotypes of Baltalı $\left(20.20^{\mathrm{g}} \%\right)$ and Çumra $(20.40 \mathrm{~g} \%)$ has the lowest values. There is a negative and significant correlation between protein rate $(\%)$ and amylose rate among the genotypes and the local genotypes of Örenpınar $\left(28.502^{\mathrm{a}} \%\right)$ and Yaşa-05 variety $\left(23.907^{\mathrm{b}}\right)$ has the highest amylose rate $(\%)$ of $28.502^{\mathrm{a}}$. Haskan local genotype has the lowest value with $12.868^{\mathrm{k}}$. We think that among the local populations, Bozkurt Çambaşı genotype which has desitype and ssp.intermedium seed characteristics and Örenpınar (ssp.arieticeps ) and Haskan (ssp.intermedium) genotype which has kabuli-type characteristics have the potential to be used as breeding material in terms of the studied characteristics.

\section{Thanks}

We would like to Prof. Dr. Hatice BOZOĞLU for her continuous support during the study and Agricultural Engineer (MSc) Merve BEZMEN for her contributions.

\section{References}

Akıncı C, Biçer BT, Eker S. 2017. Kışlık nohut hat ve çeşitlerinin değerlendirilmesi. El-Cezeri Journal of Science and Engineering, 4(3): 355-364.

Ali Q, Ahsan M, Khaliq I, Elahi M, Shahbaz M, Ahmed W, Naees M. 2011. Estimation of genetic association of yield and quality traits in chickpea (Cicer arietinum L.). Int Res J Plant Sci, 2(6): 166-169.

Anonim. 2001. Tarım ve Köy İşleri Bakanlığı Koruma ve Kontrol Genel Müdürlüğü Tohumluk Tescil ve Sertifikasyon Merkezi Müdürlüğü Tarımsal Değerleri Ölçme Denemeleri Teknik Talimat1.3-4.

Arslan U, Özçelik H, Yılmaz S. 2012. Seçilmiş bazı nohut (Cicer arietinum L.) hatlarının agronomik ve kalite özellikleri bakımından değerlendirilmesi. Akademik Ziraat Dergisi, 1(1): 29-36.

Aydoğan A. 2012. Geniş ve dar yapraklı Kabuli tip nohut (Cicer arietinum L.) çeşit ve hatlarında verim ve kalite özelliklerinin belirlenmesi. Ankara Üniversitesi Fen Bilimleri Enstitüsü, Ankara, 1.

Bayrak H. 2010. Konya ekolojisinde tarımı yapılan yerel nohut popülasyonları ve çeşitlerin tarımsal, teknolojik ve besinsel karakterlerinin belirlenmesi. Selçuk Üniversitesi Fen Bilimleri Enstitüsü, Tarla Bitkileri ABD, Konya.37.

Bayrak H, Önder M, Gezgin S. 2005. Bor uygulamasının nohut (Cicer arietinum L.) çeşitlerinde verim ve bazı verim unsurlarına etkileri. Selçuk Tarım Bilimleri Dergisi, 19(35): 66-74.

Cengiz B. 2007. Sakarya ve Eskişehir lokasyonlarında yetiştirilen bazı kuru fasulye çeşitlerinin kalite özellikleri. Namık Kemal Üniversitesi, 17-33.

Çulha G, Bozoğlu H. 2017. Amazon ve Sirma börülce çeşitlerinin tane kalitesine farklı kültürel uygulamaların etkisi. Kahramanmaraş Sütçü İmam Üniversitesi, Doğa Bilimleri Dergisi, 20: 362-366.

El-Adawy TA. 2002. Nutritional composition and antinutritional factors of chickpeas (Cicer arietinum L.) undergoing different cooking methods and germination. Plant Foods for Human Nutrition, 57: 83-97.

Encan G, Kaya M, Çiftçi CY. 2005. Nohudun dünya ve Türkiye ekonomisindeki yeri. Süleyman Demirel Üniversitesi, Fen Bilimleri Enstitüsü Dergisi, 9(1): 19-29.

Erbas Köse ÖD, Mut Z. 2020. Mineral Contents of Chickpea Cultivars (Cicer arietinum L.) Grown at Different Locations of Turkey. Sains Malaysiana 49(2): 293-303.

Erbas Köse ÖD, Mut Z. 2019. Determination of mineral content of chickpea varieties and lines grown in Turkey. DERIM, 36 (1): 73-78.FAO,2020. http://www.fao.org/faostat/en/\#data/QC [Erişim Tarihi: 21.04.2020]. 
Gil J, Nadal S, Luna D, Moreno MT, Haro AD. 1996. Variability of some physico-chemical characters in Desi and Kabuli chickpea types. Journal of the Science of Food and Agriculture, 71(2): 179-184.

Grigg D. 1995. The pattern of world protein consumption. Geoforum, 26(1): 1-17.

Gülümser A, Bozoğlu H, Pekşen E. 2008. Yemeklik baklagiller uygulama kitabı. OMÜ Ziraat Fak, 27(1): Samsun, 96-101.

Huang J, Schols HA, van Soest JJ, Jin Z, Sulmann E, Voragen A. G. 2007. Physicochemical properties and amylopectin chain profiles of cowpea, chickpea and yellow pea starches. Food Chemistry, 101(4): 1338-1345.

Jukanti AK, Gaur PM, Gowda CLL, Chibbar RN 2012. Nutritional quality and health benefits of chickpea (Cicer arietinum L.). A Review”, British Journal of Nutrition, 108: $11-26$.

Kahraman A, Ceyhan E, Harmankaya M. 2015. Nutritional variation and drought tolerance in chickpeas (Cicer arietinum L.). Journal of Elementology, 20(2).

Karakurt H, Aslantaş R, Eşitken A. 2010. Tohum çimlenmesi ve bitki büyümesi üzerinde etkili olan çevresel faktörler ve bazı ön uygulamalar. Uludă̆ Üniversitesi Ziraat Fakültesi Dergisi, 24(2): 115-128.

Karayel R. 2012. Samsun'da ekilen bezelye genotiplerinin bazı fizikokimyasal özelliklerinin belirlenmesi ve 1slah materyali olarak uygunluğunun değerlendirilmesi. OMÜ Fen Bilimleri Enstitüsü, Samsun. s:119.

Karayel R, Uzun A, Bozoğlu H. 2020. Nohut (Cicer arietinum L.)'un verim ve kalitesine ahır gübre dozlarının etkisi. Bilecik Şeyh Edebali Üniversitesi Fen Bilimleri Dergisi, 7: 285-294.

Kaur M, Singh N. 2006. Relationships between selected properties of seeds, flours, and starches from different chickpea cultivars. International Journal of Food Properties, 9(4): 597-608.

Kaya M, Karaman R, Çapar M. 2016. Göller bölgesi illerinde yetiştirilen nohut genotiplerinin bazı kalite ve teknolojik özellikleri yönünden değerlendirilmesi. Tarla Bitkileri Merkez Araştırma Enstitüsü Dergisi, 25(1): 184-190.

Khattak AB, Khattak GSS, Mahmood Z, Bibi N, Ihsanullah I. 2006. Study of selected quality and agronomic characteristics and their interrelationship in Kabuli-type chickpea genotypes (Cicer arietinum L.). International Journal of Food Science \& Technology, 41: 1-5.

Ladızınsky G, Adler A. 1976. The origin of chickpea (Cicer arietinum L.). Euphytica, 211-217. DOI: 10.1007/BF00 041547.

Miao M, Zhang T, Jiang B. 2009. Characterisations of kabuli and desi chickpea starches cultivated in China. Food Chemistry, 113(4): 1025-1032.

Mut Z, Gülümser A. 2005. Bakteri aşılaması ile birlikte çinko ve molibden uygulamasının Damla-89 nohut çeşidinin bazı kalite özellikleri. Anadolu Tarım Bilimleri Dergisi, 20(2): 110.

Özer S, Karaköy T, Toklu F, Baloch FS, Kilian B, Özkan H. 2010. Nutritional and physicochemical variation in Turkish kabuli chickpea (Cicer arietinum L.) landraces. Euphytica, 175(2): 237-249.
Pekşen E, Artık C. 2005. Antibesinsel maddeler ve yemeklik tane baklagillerin besleyici değerleri. Anadolu Tarım Bilimleri Dergisi, 20(2): 110-120.

Sağel Z, Tutluer İ, Peşkircioğlu H, Kantoğlu KY, Tümbilen Y, Kunter B, Özçoban M. 2008. TAEK-Sağel mutant nohut çeşidinin verim, kalite özellikleri ve moleküler tanımlaması. Türkiye VIII. Tarla Bitkileri Kongresi, Hatay, 19-22 Ekim.

Singh N, Sandhu KS, Kaur M. 2004. Characterization of starches separated from Indian chickpea (Cicer arietinum L.) cultivars. Journal of Food Engineering, 63(4): 441-449.

Singh U, Subrahmanyam N, Kumar J. 1991. Cooking quality and nutritional attributes of some nely developed cultivars of chickpea (Cicer arietinum). Journal of the Science of Food and Agriculture, 55(1): 37-46.

Tayade R, Kulkarni KP, Jo H, Song JT, Lee JD. 2019. Insight into the prospects for the improvement of seed starch in legume.areview. Frontiers in plant science, 10.

Tayyar S, Egesel CÖ, Gül KM, Turhan H. 2008. The effect of autumn and spring planting time on seed yield and protein content of chickpea genotypes. African Journal of Biotechnology, 7(11).

Tripathi S, Sridhar V, Jukanti AK, Suresh K, Rao BV, Gowda CLL, Gaur PM. 2012. Genetic variability and interrelationships of phenological, physicochemical and cooking quality traits in chickpea. Plant genetic resources, 10(3): 194-201.

TUIK. 2020. https://biruni.tuik.gov.tr/medas/?kn=104\&locale=tr. [Erişim Tarihi: 21.04.2020].

Varshney RK, Song C, Saxena1 RK, Azam S, Yu S, Sharpe AG, Cannon S, Baek J, Rosen BD, Tar'an B, Millan T, Zhang X, Ramsay ID, Iwata A, Wang Y, Nelson W, Farmer AD, Gaur PM, Soderlund C, Penmetsa RV, Xu C, Bharti AK, He W, Winter P, Zhao S, Hane JK, Garcia NC, Condie JA, Upadhyaya HD, Luo MC, Thudi M, Gowda CLL, Singh NP, Lichtenzveig J, Gali KK, Josefa Rubio J, Nadarajan N, Dolezel J, Bansal KC, Xu X, Edwards D, Zhang G, Kahl G, Gil J, Singh KB, Datta SK, Scott A Jackson SA, Jun Wang J, Cook DR. 2013. Draft genome sequence of chickpea (Cicer arietinum) provides a resource for trait improvement. Nature Biotechnology. 31: 240-246. doi:10.1038/nbt.2491.

Williams PC, Nakoul H, Singh KB. 1983. Relationship between cooking time and some physical characteristics in Chickpeas (Cicer arietinum L.). Journal Of The Science Of Food and Agriculture, 34(5): 492-496.

Yalçın F, Mut Z, Erbaş Köse ÖD. 2018. Afyonkarahisar ve Yozgat koşullarında yüksek verim sağlayacak uygun nohut (Cicer arietinum L.) çeşitlerinin belirlenmesi. Gaziosmanpaşa Üniversitesi Ziraat Fakültesi Dergisi, 35(1): 46-59.

Yañez-Farias GA, Moreno-Valencia JG, Falcón-Villa MDR, Barrón-Hoyos JM. 1997. Isolation and partial characterization of starches from dry beans (Phaseolus vulgaris) and Chickpeas (Cicer arietinum), grown in Sonora, Mexico. Starch-Stärke, 49(9): 341-345. 